\title{
Calculatin the Effective Intravenous Heparin Dose: Comparison between Lean and Actual Body Weight-Based Dosing in Obese Patients
}

\author{
AMR F. ABO EL FOTOUH, M.D.; NADER E. AWAD, M.D.; JANE N.R. ABOULENEIN, M.D. and \\ ASEM Sh. ABD EL KHALIQUE, M.Sc.
}

The Department of Cardiology, National Heart Institute and Faculty of Medicine, Mansoura University

\begin{abstract}
Background: Despite the availability of newer anticoagulants, unfractionated heparin remains a mainstay anticoagulant for atrial fibrillation, acute coronary syndrome with or without percutaneous intervention, treatment and prevention of deep vein thrombosis (DVT), pulmonary embolism $(\mathrm{PE})$, and other thromboembolic disorders.
\end{abstract}

Aim of Study: The aim of this study is to investigate if intravenous heparin dosing based on lean body weight (LBW) of obese patients would be safe and effective in achieving activated partial thromboplastin time (APTT) within 24 hours compared to the usual practice.

Patients and Methods: This is a case-control study conducted in Cardiology Department Sammanaud General Hospital from May 2017 to May 2018 to investigate if intravenous heparin dosing based on LBW of obese patients would be safe and effective in achieving target APTT within 24 hours compared to the usual practice. The study included 50 obese patients with a diagnosis of atrial fibrillation, suspected or confirmed deep venous thrombosis or pulmonary embolism, unstable angina or Non ST elelvation myocardial infarction with hemodynamic stability, or peripheral vascular disease. Patients aged $>18$ years randomized into two groups (1) and (2).

Results: Studies found that unfractionated heparin dosage adjustments based on the patient's LBW provided therapeutic anticoagulation more rapidly and safely, but protocols based on total body weight increase the risk of a supra-therapeutic PTT.

Conclusion: Unfractionated heparin remains a mainstay anticoagulant for atrial fibrillation, acute coronary syndrome with or without percutaneous intervention, treatment and prevention of deep vein thrombosis (DVT), pulmonary embolism (PE), and other thromboembolic disorders. As lean body weight contributes to approximately $99 \%$ of a drug's clearance, it is useful for guiding dosing in obesity. These findings may enhance the utility of LBW as body descriptor instead of TBW in calculating the effective doses of UFH in treatment of thromboembolic disorders.

Correspondence to: Dr. Amr F. Abo El Fotouh, The Department of Cardiology, National Heart Institute and Faculty of Medicine, Mansoura University
Key Words: Intravenous heparin dose - Lean body weightbased-Actual body weight-based.

\section{Introduction}

DESPITE the availability of newer anticoagulants, UFH remains a mainstay anticoagulant for atrial fibrillation, acute coronary syndrome with or without percutaneous intervention, treatment and prevention of deep vein thrombosis (DVT), pulmonary embolism (PE), and other thromboembolic disorders [1]

For the past two decades, weight-based heparin dosing nomogram has become the standard practice for treatment of thrombosis, as it has been shown to achieve rapid anticoagulation and reduce risk of recurrent thrombosis [2]

Although the guidelines endorse the weightbased strategy, they do not specify what dosing weight should be used or whether a maximum bolus dose or initial infusion rate is recommended for the treatment of DVT, PE, or atrial fibrillation [3-5].

For many years, patients received a standard dosage of unfractionated heparin (UFH), consisting of a 5000-U bolus followed by a 1000-U/hour infusion, for treatment of venous and arterial thrombosis. Later, studies found that UFH dosage adjustments based on the patient's weight provided therapeutic anticoagulation more rapidly [6-8]

Weight-adjusted nomograms have provided an advantage over standard UFH dosing. In one study, a greater percentage of patients achieved an initial APTT greater than 1.5 times the control with weight-based UFH dosing (86\%) compared with standard dosing (32\%) [9]. 
Patient management strategies include dosing based on total body weight, ideal body weight (IBW), adjusted body weight, or total body weight with a reduced infusion rate. Protocols based on total body weight increase the risk of a supratherapeutic APTT; however no increase in bleeding has been reported [10].

The volume of distribution for UFH is similar to that of blood volume, $40-70 \mathrm{ml} / \mathrm{kg}$. Although obese patients have a larger blood volume, adipose tissue contains a lower blood volume than lean tissue $[\mathbf{1 1 , 1 2 ]}$.

Lean Body Weight (LBW) is based on the formula by Janmahasatian et al. [13]; Male $=[9270 \mathrm{x}$ weight $(\mathrm{kg})] /[6680+216 \times$ BMI $]$ Female $=[9270$ $\mathrm{x}$ weight $(\mathrm{kg})] /[8780+244 \mathrm{x} \mathrm{BMI}]$.

\section{Aim of the work:}

The aim of this study is to investigate if intravenous heparin dosing based on LBW of obese patients indicated for UFH therapy would be safe and effective in achieving APTT within 24 hours compared to the usual practice.

\section{Patients and Methods}

This is a case-control study conducted in the Cardiology Department Sammanaud General Hospital from May 2017 to May 2018 to investigate if intravenous heparin dosing based on LBW of obese patients would be safe and effective in achieving target aPTT within 24 hours compared to the usual practice.

\section{Patients:}

The study included 50 obese patients with a diagnosis of atrial fibrillation, suspected or confirmed deep venous thrombosis or pulmonary embolism, unstable angina or non ST elevation myocardial infarction with hemodynamic stability, or peripheral vascular disease. Patients aged $>18$ years randomized into two groups (1) and (2).

First group (control): Received UFH based on actual body weight at an initial infusion rate of (12-16) units/kg/h.

Second group (cases): Who received UFH based on lean body weight at the same rate.

Serial APTT measured every 6 hours for all patients.

A standardized nomogram is used to achieve a goal APTT of 57-84 sec (normal range, goal APTT 1.5-2.5 x normal) or 57-70 sec (low range, 1.5-2 $\mathrm{x}$ normal).
The primary endpoint was UFH dosage and time achieving therapeutic APTT within first 24 hours for each group.

The Secondary endpoint was major bleeding that included documented cerebral, gastrointestinal or retroperitoneal bleeding as well as minor bleeding e.g; ecchymosis, epistaxis, hematoma, hematuria hemoptysis, petechiae or oozing.

\section{Inclusion criteria:}

- Patients with body mass index greater than or equal to $30 \mathrm{~kg} / \mathrm{m}^{2}$.

-Weight-based intravenous heparin.

- Patient consent.

Exclusion criteria:

- Patients with stroke, TIA, or ST elevation myocardial infarction

- Patients who have hemodynamic or cardiopulmonary instability.

- Patients with thrombophilia

- Patients who are pregnant.

- Patients who have been on any oral anticoagulants (Warfarin, rivaroxaban, dabigatran or apixaban), treatment dose of other anticoagulants or intravenous thrombolytics in previous 7 days.

- Patients who have APTT greater than 37 seconds.

- History of heparin-induced thrombocytopenia or allergy to heparin.

\section{Methods:}

The nature of the study was explained to all participants. An informed consent was taken from all participants in the research and the privacy of the data was greatly considered.

All patients were subjected to: Clinical assessment:

Detailed history and clinical examination were performed with special emphasis on:

1- Cardiovascular diseases symptoms:

a- Chest pain; typical or atypical, site, nature, duration, radiation, frequency, precipitating factors, relieving factors.

b- Palpitation; suspect IHD, AF.

c- Dyspnea; relation to exercise, tachypnea.

2- DVT symptoms:

Lower limb; pain, swollen, limited mobility.

3- Cerebrovascular Stroke symptoms:

Motor deficit, loss of sensation, autonomic neuropathy. 


\section{4- Drugs:}

Using oral anticoagulants (Warfarin, rivaroxaban, dabigatran or apixaban), treatment dose of other anticoagulants or intravenous thrombolytics in previous 7 days, thrombophilia, hypersensitivity to UFH.

5- Anthropometric measurements:

The following measurements were obtained:

a- Height and weight.

b- Body mass index (BMI): It was calculated using the following formula.

BMI $=$ Weight $(\mathrm{kg}) /[\text { height }(\mathrm{m})]^{2}$

Obesity is defined as BMI $\geq 30 \mathrm{Kg} / \mathrm{m}^{2}$

6- Electrocardiography:

12-lead ECG was done for detection of Coronary artery disease and arrhythmias.

7- Pulmonary CT angiography:

For patients who suspected to have pulmonary embolism.

8- Lower limb duplex:

For patients who suspected to have deep vein thrombosis.
9- Laboratory work-up:

a- Complete blood picture; for detection platelets number.

b- APTT at admission time and every 6 hours.

c- Cardiac enzymes for patients who suspected to have NSTEMI.

10- Lean Body Weight (LBW) is based on the formula by Janmahasatian et al.; Male $=[9270$ $\mathrm{x}$ weight $(\mathrm{kg})] /[6680+216 \times \mathrm{BMI}]$ Female $=$ [9270 x weight $(\mathrm{kg})] /[8780+244 \times \mathrm{BMI}]$ [13]

\section{Statistical analysis:}

The collected data were coded, processed and analyzed using the SPSS (Statistical Package for Social Sciences) version 22 for Windows ${ }^{\circledR}$ (SPSS Inc, Chicago, IL, USA). $p<0.05$ was considered to be statistically significant. $t$ : Independent samples $t$-test (comparison of normally distributed quantitative data). $\chi$ : Chi-square test (Comparison of categorical data). Z: Mann-Whitney test (comparison of abnormally distributed quantitative data).

\section{Results}

Table (1): Comparison of the demographic data in the two groups.

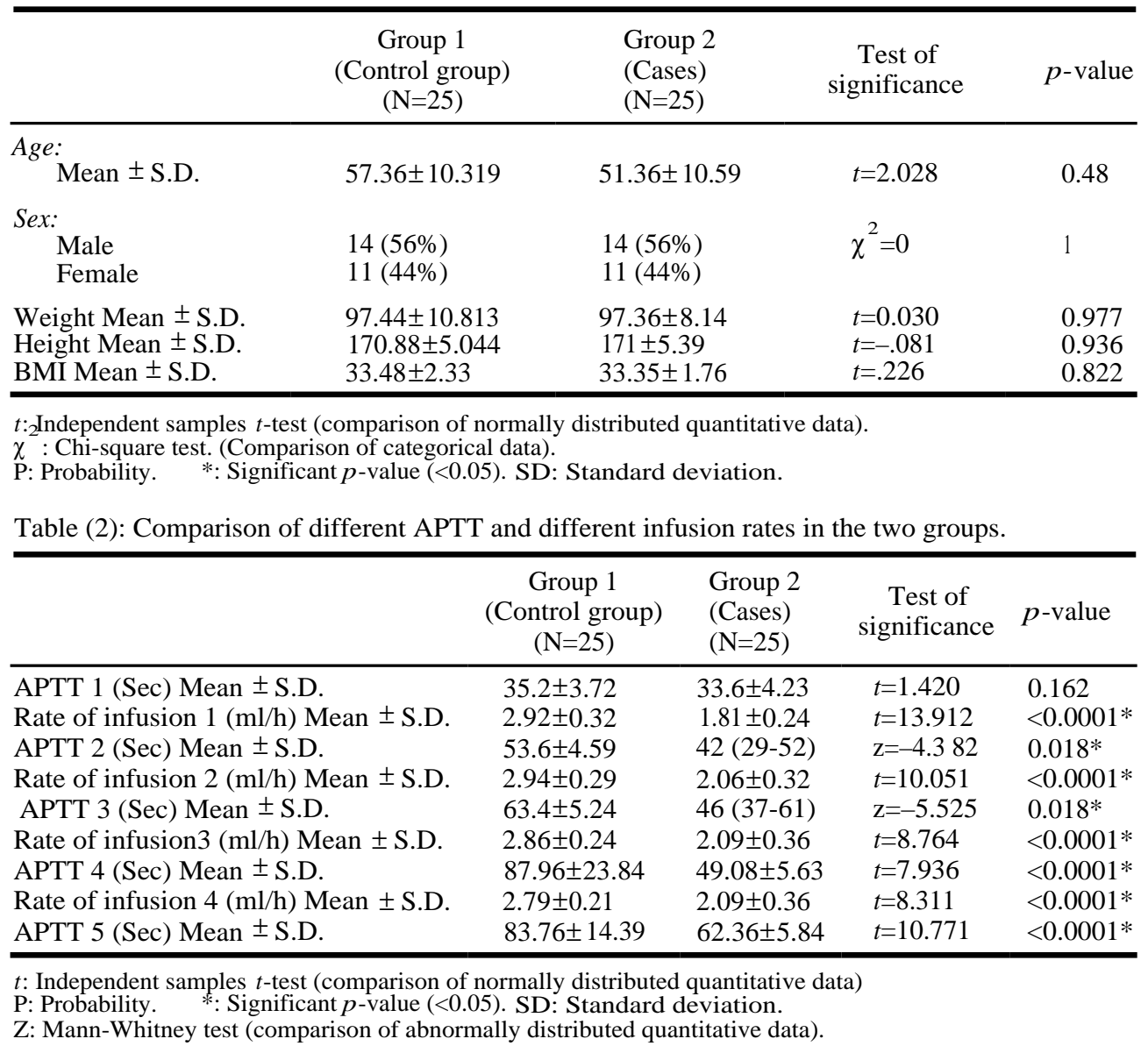


Table (3): Comparison between APTT at different time points in control group.

\begin{tabular}{llllll}
\hline & APTT1 & APTT2 & APTT3 & APTT4 & APTT5 \\
\hline Mean \pm SD & $35.2 \pm 3.72$ & $53.6 \pm 4.59$ & $63.4 \pm 5.24$ & $87.96 \pm 23.84$ & $83.76 \pm 14.39$ \\
$p_{1}$ & $<0.0001^{*}$ & $<0.0001^{*}$ & $<0.0001^{*}$ & $<0.0001^{*}$ \\
$p_{2}$ & & $<0.0001^{*}$ & $<0.0001^{*}$ & $<0.0001^{*}$ \\
$p_{3}$ & & & $0.013^{*}$ & 0.234 \\
$p_{4}$ & & & & 0.118 \\
\hline p1: Significance relative to Aptt1. & Test used: Paired samples $t$-test (comparison of normally distributed \\
p2: Significance relative to Aptt2. & quantitative data in the same groups at different time points). \\
p3: Significance relative to Aptt3; & P : Probability. & & \\
p4: Significance relative to Aptt4. & * : Significant $p$-value (<0.05). & & \\
& & SD: Standard deviation. &
\end{tabular}

Table (4): Comparison between APTT at different time points in cases group.

\begin{tabular}{|c|c|c|c|c|c|}
\hline & APTT1 & APTT2 & APTT3 & APTT4 & APTT5 \\
\hline $\begin{array}{l}\text { Mean } \pm \text { SD } \\
p_{1} \\
p_{2} \\
p_{3} \\
p_{4}\end{array}$ & $33.6 \pm 4.23$ & $\begin{array}{l}46.6 \pm 6.5 \\
<0.0001 *\end{array}$ & $\begin{array}{l}46.4 \pm 5.69 \\
<0.0001 * \\
<0.0001 *\end{array}$ & $\begin{array}{l}49.08 \pm 5.63 \\
<0.0001 * \\
<0.0001 * \\
0.032 *\end{array}$ & $\begin{array}{l}62.36 \pm 5.84 \\
<0.0001 * \\
<0.0001 * \\
0.001 * \\
0.126\end{array}$ \\
\hline $\begin{array}{l}\text { p1: Signific } \\
\text { p2: Signific } \\
\text { p3: Signific } \\
\text { p4: Signific }\end{array}$ & $\begin{array}{l}\text { elative to Aptt } \\
\text { elative to Aptt } \\
\text { elative to Aptt } \\
\text { elative to Aptt }\end{array}$ & \multicolumn{4}{|c|}{$\begin{array}{l}\text { Test used: Paired samples } t \text {-test (comparison of normally distributed } \\
\text { quantitative data in the same groups at different time points). } \\
\text { P : Probability. } \\
* \text { : Significant } p \text {-value }(<0.05) \text {. } \\
\text { SD: Standard deviation. }\end{array}$} \\
\hline
\end{tabular}

Table (5): Comparison between infusion rates at different time points in control group.

\begin{tabular}{lcccc}
\hline & Infusion rate 1 & Infusion rate 2 & Infusion rate 3 & Infusion rate 4 \\
\hline Mean \pm SD & $2.92 \pm 0.32$ & $2.94 \pm 0.29$ & $2.86 \pm 0.24$ & $2.79 \pm 0.21$ \\
$p_{1}$ & 0.572 & 0.215 & $0.026^{*}$ \\
$p_{2}$ & & $0.026^{*}$ & $0.001 *$ \\
$p_{3}$ & & & $<0.0001 *$ \\
\hline p1: Significance relative to infusion rate 1. & Test used: Paired samples $t$-test (comparison of normally \\
p2: Significance relative to infusion rate 2. & \multicolumn{2}{c}{ at different quantitative data in the same groups } \\
p3: Significance relative to infusion rate 3. & P : Probability. * Significant $p$-value (<0.05). \\
& SD: Standard deviation
\end{tabular}

Table (6): Comparison between infusion rates at different time points in cases group.

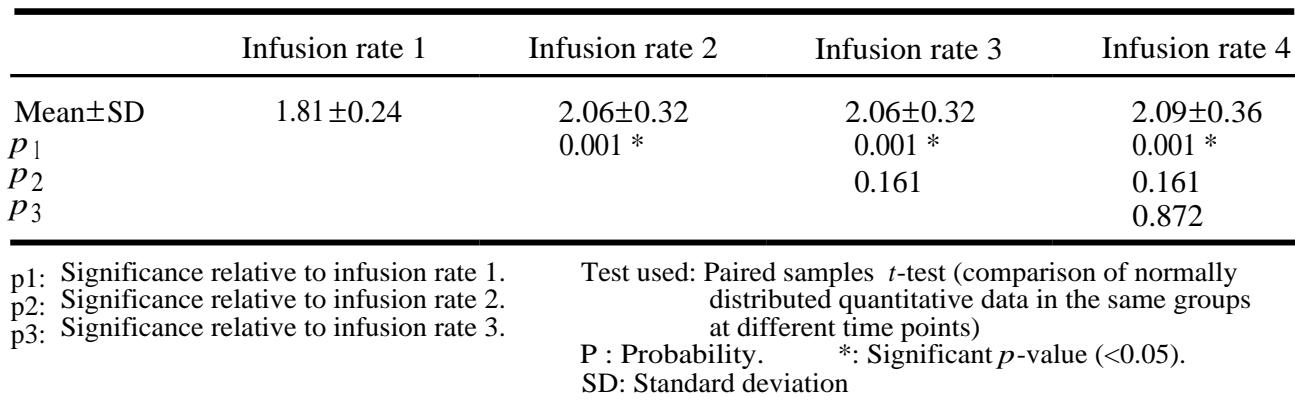

Table (7): Comparison between achievements of the target APTT $(57-83 \mathrm{sec})$ within 24 hours in the two study groups.

\begin{tabular}{lclcr}
\hline & $\begin{array}{c}\text { Group 1 } \\
(\text { Control group }) \\
(\mathrm{N}=25)\end{array}$ & $\begin{array}{l}\text { Group 2 } \\
(\text { Cases }) \\
(\mathrm{N}=25)\end{array}$ & $\begin{array}{c}\text { Test of } \\
\text { significance }\end{array}$ & $p$-value \\
\hline Achieved & $15(60 \%)$ & $\begin{array}{l}25(100 \%) \\
\text { Not-achieved }\end{array}$ & $\chi^{2}=12.5$ & $0.001 *$ \\
\hline
\end{tabular}

$\chi^{2}$ : Chi-square test. (Comparison of categorical data). P: Probability. *: Significant $p$-value $(<0.05)$. 


\section{Discussion}

Despite the availability of newer anticoagulants, unfractionated heparin remains a mainstay anticoagulant for atrial fibrillation, acute coronary syndrome with or without percutaneous intervention, treatment and prevention of deep vein thrombosis (DVT), pulmonary embolism (PE), and other thromboembolic disorders [1]

According to $_{2} \mathrm{WHO}$, obesity is defined as a BMI $\geq 30 \mathrm{~kg} / \mathrm{m}[\mathbf{1 4}, 15]$, obesity rates have nearly doubled since 1980. In 2008, an estimated 1.5 billion adults over the age of 20 years $(35 \%)$ were overweight, and 500 million (11\%) were obese [16].

Studies found that UFH dosage adjustments based on the patient's weight provided therapeutic anticoagulation more rapidly [6-8]. Although the guidelines endorse the weight-based strategy, they do not specify what dosing weight should be used [3-5].

To our knowledge, this is the first study that has explored calculating of the effective intravenous heparin dose by comparison between lean body weight-based dosing and actual body weight based dosing in obese patients; our study group consisted of 50 patients divided into two groups:

- Group 1 (control): 25 obese patients indicated for receiving UFH; received UFH at Actual Body Weight-based Doses.

- Group 2 (cases): 25 obese patients indicated for receiving UFH; received UFH at Lean Body Weight-based Doses.

We noticed that the count of patients who achieved the target APTT (57-83sec) within 24 hours in group 2 was $25(100 \%)$ while in control group the count of patients who achieved the target APTT within 24 hours was 15 (60\%).

The infusion rates at different time points in group I; the infusion rate 1 Mean \pm SD was 2.92 \pm 0.32 , infusion rate 2 Mean \pm SD was $2.94 \pm 0.29$, infusion rate 3 Mean \pm SD was $2.86 \pm 0.24$, infusion rate 4 Mean $\pm \mathrm{SD}$ was $2.79 \pm 0.21$.

The infusion rates at different time points in group II; the infusion rate 1 Mean \pm SD was $1.81 \pm$ 0.24 , infusion rate 2 Mean \pm SD was $2.06 \pm 0.32$, infusion rate 3 Mean \pm SD was $2.06 \pm 0.32$, infusion rate 4 Mean \pm SD was $2.09 \pm 0.36$.

In our study it is clear that, by using the LBW in cases group instead of TBW in control group for calculating the therapeutic doses of UFH, we achieved the targeted APTT in all (100\%) patients effectively, safely, with less infusion rates and no increase in risk of bleeding or cause supra therapeutic range, while in control group we achieved the targeted APTT only in $60 \%$ of patients with increasing risk of bleeding and being supra therapeutic range.

Due to the varying anticoagulant response of UFH among patients, UFH therapy is monitored and the dose is adjusted based on these results. The test most often used to monitor heparin is the activated partial thromboplastin time (APTT).

An APTT ratio between 1.5 and 2.5 (calculated by dividing the reported therapeutic APTT range by the control value for the reagent) was associated with a reduced risk for recurrent VTE in a previous large retrospective registry. Using total body weight assumes that the pharmacokinetics of the drug are linearly scalable from normal-weight patients to those who are obese, this is inaccurate; For example, we cannot assume that a $150 \mathrm{~kg}$ patient eliminates a drug twice as fast as a $75 \mathrm{~kg}$ patient and therefore double the dose so clinicians are alert to toxicities with higher doses, for example bleeding with anticoagulants $[\mathbf{1 7 , 1 8 , 1 9 ]}$

In concordance with our results Hanley et al., reported that drug clearance is correlated to lean rather than adipose weight as adipose tissue has little metabolic activity and as clearance determines a drug's maintenance dose, clinicians should consider how lean body weight, rather than total body weight, impacts dosing. When lean body weight increases there will be a corresponding increase in drug clearance and an increased dose may be required [17]

Hanely et al., also concluded that using a lean body weight metric encompasses a more scientific approach to weight-based dosing. Lean body weight reflects the weight of all 'non-fat' body components, including muscle and vascular organs such as the liver and kidneys. As lean body weight contributes to approximately $99 \%$ of a drug's clearance, [17] it is useful for guiding dosing in obesity.

Pai et al., reported that hydrophilic drugs e.g. heparins typically remain in extracellular fluid and their volume of distribution correlates with lean mass, this implies that the distribution of hydrophilic drugs should not be significantly influenced by excess adipose tissue [18]

\section{Conclusion:}

Unfractionated heparin remains a mainstay anticoagulant for atrial fibrillation, acute coronary 
syndrome with or without percutaneous intervention, treatment and prevention of deep vein thrombosis (DVT), pulmonary embolism (PE), and other thromboembolic disorders. Hydrophilic drugs (e.g. heparins) typically remain in extracellular fluid and their volume of distribution correlates with lean mass. This implies that the distribution of hydrophilic drugs should not be significantly influenced by excess adipose tissue. As lean body weight contributes to approximately $99 \%$ of a drug's clearance, it is useful for guiding dosing in obesity. These findings may enhance the utility of LBW as body descriptor instead of TBW in calculating the effective doses of UFH in treatment of thromboembolic disorders.

\section{References}

1- Heparin [monograph]. In: Lexicomp Online [online Database]. Hudson, OH: Lexi-Comp (accessed 2015 May 12). https://online.lexi.com

2- RASCHKE R.A., REILLY B.M., GUIDRY J.R., et al.: The weight-based heparin dosing nomogram compared with a "standard care" nomogram. A randomized controlled trial. Ann. Intern. Med., 119 (9): 874-881, 1993.

3- GARCIA D., BAGLIN T.P., WEITZ J.I. and SAMAMA M.M.: Parenteral anticoagulants = Antithrombotic therapy and prevention of thrombosis, 9 th ed: American College of Chest Physicians evidence-based clinical practice guidelines. Chest, 141 (2 Suppl): e24S-43S, 2012.

4- KEARON C., AKL E.A., COMEROTA A.J., et al.: Antithrombotic therapy for VTE disease: Antithrombotic therapy and prevention of thrombosis, 9 th ed: American College of Chest Physicians evidence-based clinical practice guidelines. Chest, 141 (2 Suppl): e419S-e494S, 2012.

5- YOU J.J., SINGER D.E., HOWARD P.A., et al.: Antithrombotic therapy for atrial fibrillation: Antithrombotic therapy and prevention of thrombosis, 9 th ed: American college of chest physicians evidence-based clinical practice guidelines. Chest, 141 (2 Suppl): e531S-e575S, 2012.

6- SAYA F.G., COLEMAN L.T. and MARTINOFF J.T.: Pharmacist-directed heparin therapy using a standard dosing and monitoring protocol. Am. J. Hosp. Pharm., 42: 1965-9, 1985.

7- HULL R.D., RASKOB G.E., ROSENBLOOM D., et al.: Optimal therapeutic level of heparin therapy in patients with venous thrombosis. Arch. Intern. Med., 152: 158995, 1992.

8- RIVEY M.P. and PETERSON J.P.: Pharmacy-managed, weight-based heparin protocol. Am. J. Hosp. Pharm., 50: 279-84, 1993.
9- RASCHKE R.A., REILLY B.M., GUIDRY J.R., FONTANA J.R. and SRINIVAS S.: The weight-based heparin dosing nomogram compared with 'standard care' nomogram. Ann. Intern. Med., 119: 874-81, 1993.

10- BARLETTA J.F., DeYOUNG J.L., McALLEN K., BAKER R. and PENDLETON K.: Limitations of a standardized weight-based nomogram for heparin dosing in patients with morbid obesity. Surg. Obes. Relat. Dis., 4: 748-753, 2008.

11- RYAN T.J., ANTMAN E.M., BROOKS N.H., et al. 1999 update: ACC/AHA guidelines for the management of patients with acute myocardial infarction: A report of the American College of Cardiology/American Heart Association task force on practice guidelines (committee on management of acute myocardial infarction). J. Am. Coll. Cardiol., 34: 890-911, 1999.

12- BRAUNWALD E., ANTMAN E.M., BEASLEY J.W., et al.: ACC/AHA 2002 guideline update for the management of patients with unstable angina and non-ST-segment elevation myocardial infarction: A report of the American College of Cardiology/American Heart Association task force on practice guidelines (committee on management of patients with unstable angina), Circulation, 106: 18931900, 2002.

13- JANMAHASATIAN S., DUFFULL S.B., ASH S., et al.: Quantification of lean bodyweight. Clin. Pharmacokinet., 44 (10): 1051-65, 2005.

14- World Health Organization. Obesity: Preventing and managing the global epidemic. Report of a WHO consultation. World Health Organ Tech. Rep. Ser., 894: 1-253, 2000.

15- Expert Panel on the Identification, Evaluation, and Treatment of Overweight and Obesity in Adults. Clinical guidelines on the identification, evaluation, and treatment of overweight and obesity in adults - the evidence report - NIH PUBLICATION NO. 98-4083. In: National Institutes of Health, editor. Bethesda: National Institutes of Health, 1998.

16- Source: Modified from WHO Expert Consultation Appropriate body-mass index for Asian populations and its implications for policy and intervention strategies. Lancet, 363: 157-163, 2004.

17- HANLEY M.J., ABERNETHY D.R. and GREENBLATT D.J.: Effect of obesity on the pharmacokinetics of drugs in humans. Clin. Pharmacokinet., 49: 71-87, 2010.

18- PAI M.P. and PALOUCEK F.P.: The origin of the "ideal" body weight equations. Ann. Pharmacother., 34: 1066-9, 2000.

19- MORRISH G.A., PAI M.P. and GREEN B.: The effects of obesity on drug pharmacokinetics in humans. Expert Opin. Drug Metab. Toxicol., 7: 697-706, 2011. 


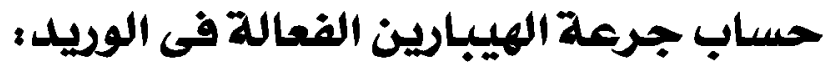

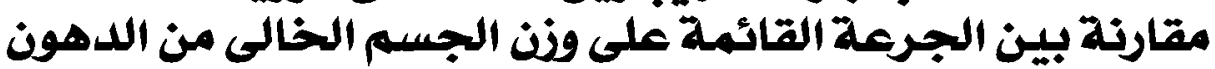

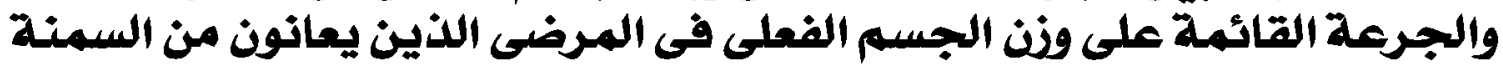

مقدمة: بالرغم من توافر مضادات تخثر أحدث إلا أن الهييارين سيظل مشاد التخثر الأساسى فى حالات الرجفان الأذينى ومتالازمة الشريان التاجى الحاد وجلطات الأوددة العميقة والسدة الرئوئية.

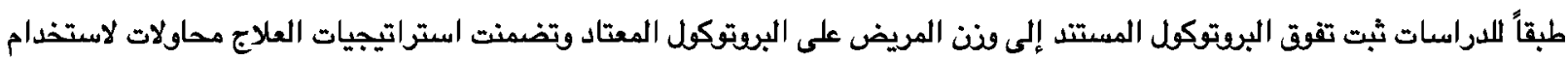

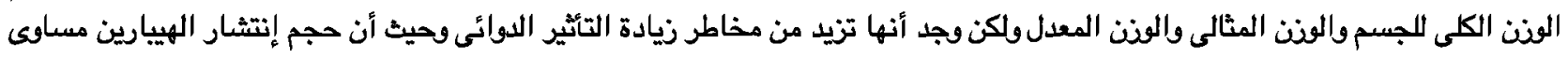

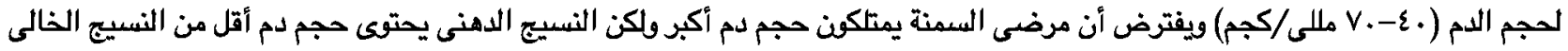

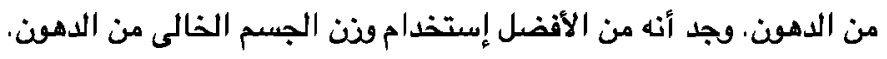
الهدف من البحث: التحرى عما إذا كانت جرعات الهيبارين المستندة على ونت المريض الخالى من الدهون آمنة وفعالة لتحقيق التأثير

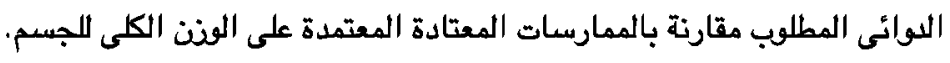
طريقة البحث: إشتمل هذا البحث على •0 مريض مقسمين إلى مجموعتين:

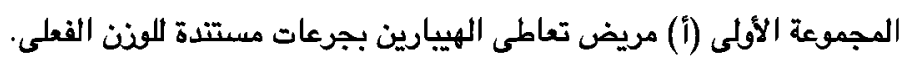
المجموعة الثانية (ب) مريض تعاطى الهييارين بجرعات مستندة للونن الخالى من الدهون.

$$
\text { تم عمل الآتى لكل المرضى طبيعة البحث وأخذ موافقة من جميع المرضى. }
$$

تم أخذ تاريخ مرضى وفحص إكلينيكى قمنا فيه بالتركيز على أعراض قصود الثرايين التاجية واللانظمية القلبية والتاريخ الدائى خاصة أدوية مانعة التخثر.

تم قياس الوذن الكلى وحساب الوذن الخالى من الدهون طبقاً للمعادلة الأتية:

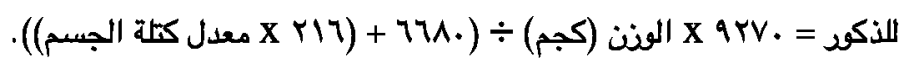

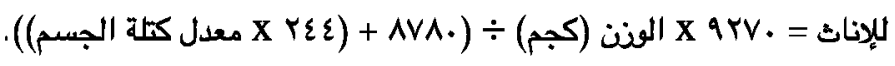
تم سحب عينات الدم منهم لمعرفة زمن الثرمبوبلاستين الجزئى النثط عند الدخول وكل ست ساعات مع تعديل معدل تعاطى الهيبارين طبقاً للنتيجة. وقد أظهرت الدراسة هذه النتائج: أنه فى الجموعة الأولى (1) حققنا زمن الترمبوبلاستين الجزئى النشط المستهدف فى ـ ـ/ من المرضى فقط بالإضافة إلى زيادة مخاطر النزيف وتحقيق زمن أكبر من المطلوبي

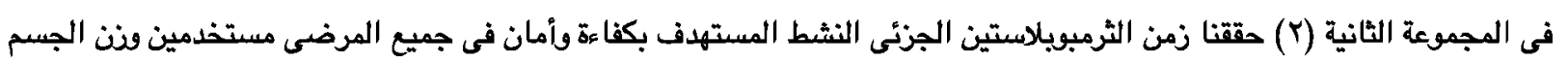
الخالى من الدهن.

ومذا يؤكد على مدى فاعلية وأمان استخدام ونن الجسم الخالى من الدهون بدلا من الونن الكلى لحساب جرعات الهيبارين المستخدمة

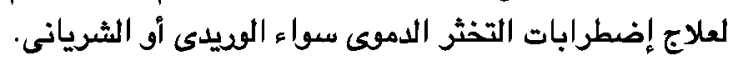

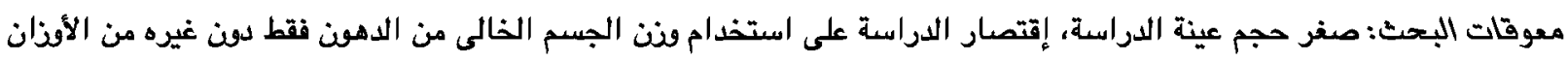

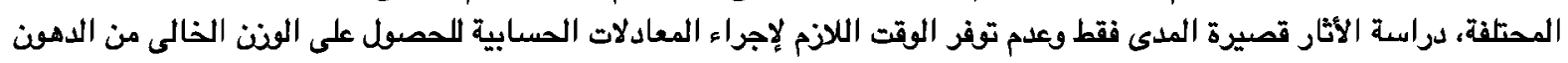

